\title{
Correspondence
}

http://dx.doi.org/10.11646/phytotaxa.278.2.9

\section{Pycnandra longiflora (Sapotaceae) a species believed to be extinct, rediscovered in New Caledonia}

\author{
JÉRÔME MUNZINGER ${ }^{1} \&$ ULF SWENSON \\ ${ }^{I} I R D$, UMR AMAP, Laboratoire de Botanique et d'Écologie végétale appliquées, Herbier NOU, F-98848 Nouméa (Nouvelle-Calédonie) \\ et IRD, UMR AMAP, F-34000 Montpellier (France).email: jerome.munzinger@ird.fr \\ ${ }^{2}$ Department of Botany, Swedish Museum of Natural History, PO Box 50007, 10405 Stockholm (Sweden).
}

Pycnandra longiflora (Sapotaceae) belongs to the largest endemic genus in New Caledonia. It is only known from the type collection made in 1861-67 at the obscure locality "Gatope". Relocation of this species has been of high priority for more than a decade, but without success. Pycnandra longiflora was therefore recently declared extinct. However, a population was recently discovered near a mining site at Onajiele, in the Ouazangou-Taom massif, and it is revealed that $P$. longiflora has the most spectacular flowers in the entire genus, being large and bicoloured in red and yellow. A thorough description is here outlined and we propose a preliminary IUCN status as Critically Endangered.

Key words: Extinct species, rediscovering, extended description, prospection

Sapotaceae was the first plant family to be treated for Flore de Nouvelle-Calédonie et Dépendances with 80 recognized species at that time (Aubréville 1967). Identification of genera and species has been highly problematic due to doubtful generic limitations and insufficient material for proper species description. In the 1990s several putative new species were tentatively proposed, which were believed to be threatened with extinction, including "Leptostylis sp.1 V.6850" and "Planchonella sp.1 V.6585" (Jaffré et al. 1998). Other species were considered doubtful since they were only known from the type collections made in the 1860s, including Planchonella vieillardii (Baill.) Dubard (1912: 58) from Gatope, Leptostylis micrantha Beauvisage (1901: 88) from Art Island, and L. longiflora Bentham in Bentham \& Hooker (1876: 659), also from Gatope (Bouchet et al. 1995). Revision of the family for New Caledonia was clearly needed, a work we embarked on more than a decade ago, resulting in a new generic classification (Bartish et al. 2005; Swenson et al. 2007a, 2008, 2013, 2015) as well as 42 new species endemic for New Caledonia (Swenson et al. 2007b, 2009, 2010a, 2010b, 2010c, 2012, 2016; Munzinger \& Swenson 2009, 2015; Munzinger 2015).

Leptostylis Bentham was revised by Vink (1957), who described three new species, accepted seven in total, and selected L. longiflora as the type of the genus, despite it being only known from the type collection. The type was collected in 186167 at Gatope by Émile Deplanche (1824-1874), a French naval surgeon and botanist (Morat 2010). Leptostylis is readily identified by its opposite leaves and four sepals, but the group is nested within Pycnandra and was relegated to subgeneric level to maintain monophyly (Swenson \& Munzinger 2009; Swenson et al. 2015). Nevertheless, subgenus Leptostylis was in urgent need of revision in order to sort out several taxonomic problems and to enable transfer of the recognised species to Pycnandra. We therefore undertook extensive fieldwork in New Caledonia and in particular Dominique Fleurot intensively searched the maquis vegetation in the Gatope Peninsula near Koné in the hope of relocating P. longiflora. All in all, 413 individuals of Pycnandra were found, but all belonged to another species, P. filipes subsp. filipes (Bentham) Munzinger \& Swenson (2015: 97). Unable to relocate P. longiflora, we eventually considered the species to be extinct (Munzinger \& Swenson 2015; Swenson \& Munzinger 2016), a conclusion that we here fortunately can reject.

Our publications alerted an amateur botanist, Rosa Scopetra, in November 2015 that a species she had followed for years could possibly be the presumed extinct species Pycnandra longiflora. Recently, she sent pictures and specimens with flowers and fruits to one of us (JM in Montpellier), material easily confirmed as the plant unseen for 150 years -Pycnandra longiflora. We were at once astonished by the spectacular bicoloured flowers with red tubes and yellow corolla lobes that matched the type collection from which the colour cannot be deduced (Fig. 1). Without doubt, P. longiflora has the largest and the most beautiful flowers in the entire genus. With this unexpected rediscovery it is possible to complete the description of a very rare species and change the proposed IUCN status from Extinct to Critically Endangered. 


\section{Material and methods}

We used herbarium specimens [Munzinger leg. Scopetra 7519, 7522], flowers and fruits preserved in alcohol, images, and field observations (including individuals counted) by Rosa Scopetra. We apply IUCN criteria (IUCN 2012) for evaluating threat status, using 'Geocat' software online (Bachman et al. 2011) to calculate extent of occurrence (EOO) and area of occupancy (AOO). A topographic image of the population's distribution was made with the software ArcGIS $\odot$ by using georeferenced individuals" (excluding the type locality).

\section{Pycnandra longiflora (Benth.) Munzinger \& Swenson, Austral. Syst. Bot. 28: 101 (2015) (Fig. 1)}
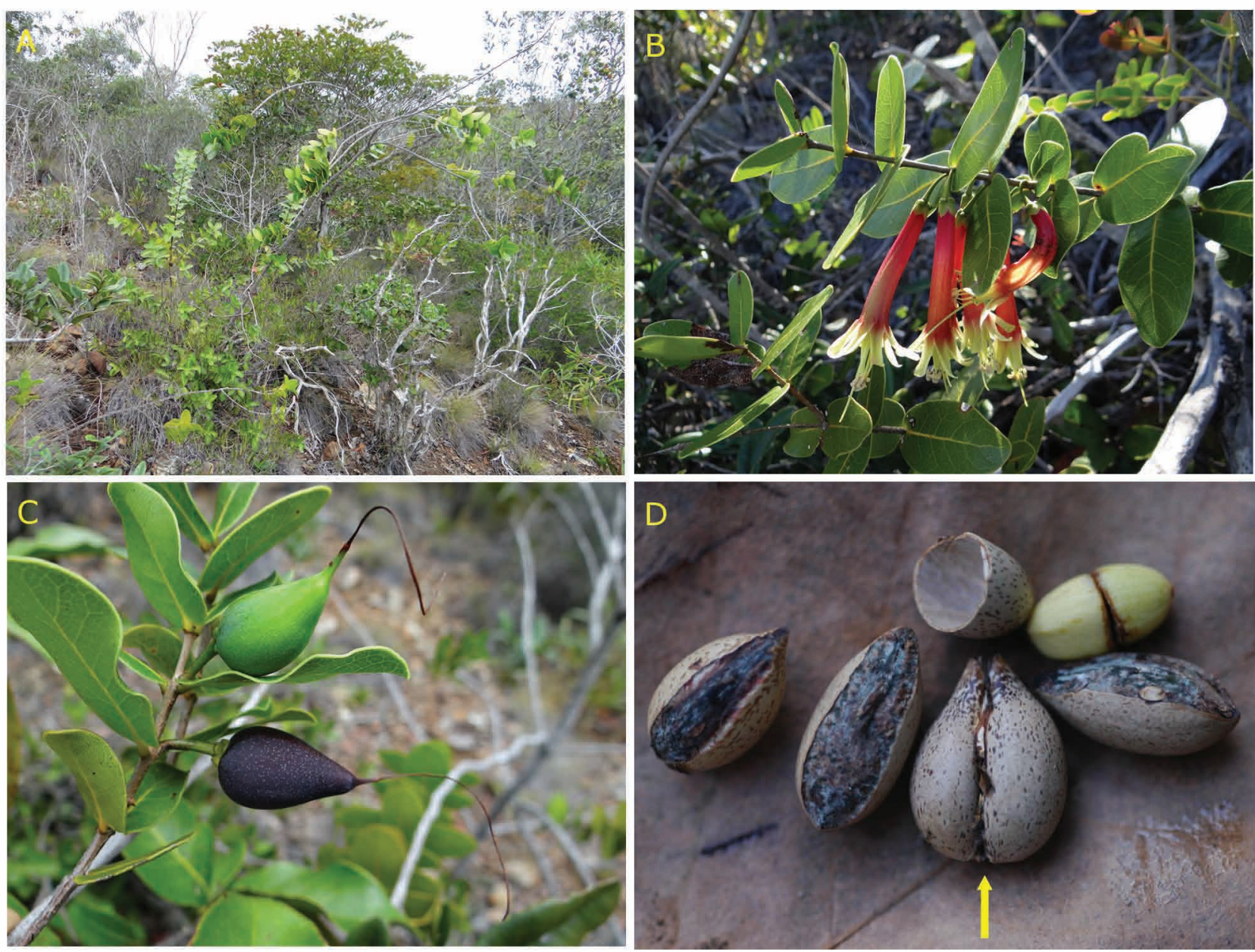

FIGURE 1. Pycnandra longiflora, A. Habit of open maquis, B. Flowering branch, C. Fruits with long persistent styles, D. Seeds from one- or 2-seeded (arrow) fruits. Pictures A-C from Rosa Scopetra, D from Jérôme Munzinger.

\section{Expanded description}

Slender shrub usually $1.7 \mathrm{~m}$ tall (to rarely $4 \mathrm{~m}$ tall), with grey-brownish branches. Leaves opposite, subsessile, obovate, narrowly obovate or suborbicular, small, glabrous, coriaceous, $1.3-4.0(-7.5) \times 0.9-3.5(-4.0) \mathrm{cm}$; base round to cordate; secondary venation usually of 5 pairs; tertiary veins indistinguishable. Flowers axillary and solitary; pedicels filiform, $\sim 12$ $\mathrm{mm}$ long, glabrous. Sepals $\sim 3 \mathrm{~mm}$ long, ovate, glabrous. Corolla tubular, red, $30-32 \mathrm{~mm}$ long; corolla lobes 6-8, pale yellow, oblong, 6-7 mm long. Stamens inserted slightly below the tube orifice, exserted; filaments filiform, $\sim 12 \mathrm{~mm}$ long; anthers 2.5-3.5 mm long. Gynoecium conical, pubescent around the base; ovary $1.5 \times 1.0 \mathrm{~mm}$; style filiform, up to $50 \mathrm{~mm}$ long in flowering specimens, well exserted and available for pollinators, glabrous, of the same colour as the corolla lobes and filaments. Fruit pyriform, widest at the base, 20-25 x 8-10 mm (slightly flattened and $15 \mathrm{~mm}$ wide if containing two seeds), black when mature, glabrous, with a 35-50 mm long persistent style; seeds usually $1,17-21 \times 8-10 \mathrm{~mm}$, ovoid; testa pale brown, thin $(0.5 \mathrm{~mm})$, usually with reddish dots; seed scar oval to narrowly ovate, $15-20 \%$ of seed circumference and $100 \%$ of the seed length, with nearly parallel margins; cotyledons plano-convex, cream, smooth, endosperm absent. 


\section{Ecology}

Pycnandra longiflora occurs on hypermagnesium brown soils in quite open maquis, between 55 and $140 \mathrm{~m}$ elevation (Fig. 1A). The shape of the flowers, with long tube and well-exposed stamens and style, indicates that it is probably bird pollinated (Faegri \& Van Der Pijl 1979).

\section{Conservation status}

The newly revealed locality of Pycnandra longiflora is near Onajiele in the Ouazangou-Taom massif. The species occurs at two adjacent sites and has a calculated EOO of $0.6 \mathrm{~km}^{2}$ and AOO of $8 \mathrm{~km}^{2}$. One hundred and seventy six individuals have been counted in this very limited area that easily could be ruined by a single fire, forest clearance, or an enlargement of the truck access to the mining concession (Fig. 2). Thus, following the IUCN terminology and recommendations, $P$. longiflora occurs on a single location and is therefore best assigned a preliminary IUCN status as Critically Endangered [CR B1ab(iii)+2ab(iii)].

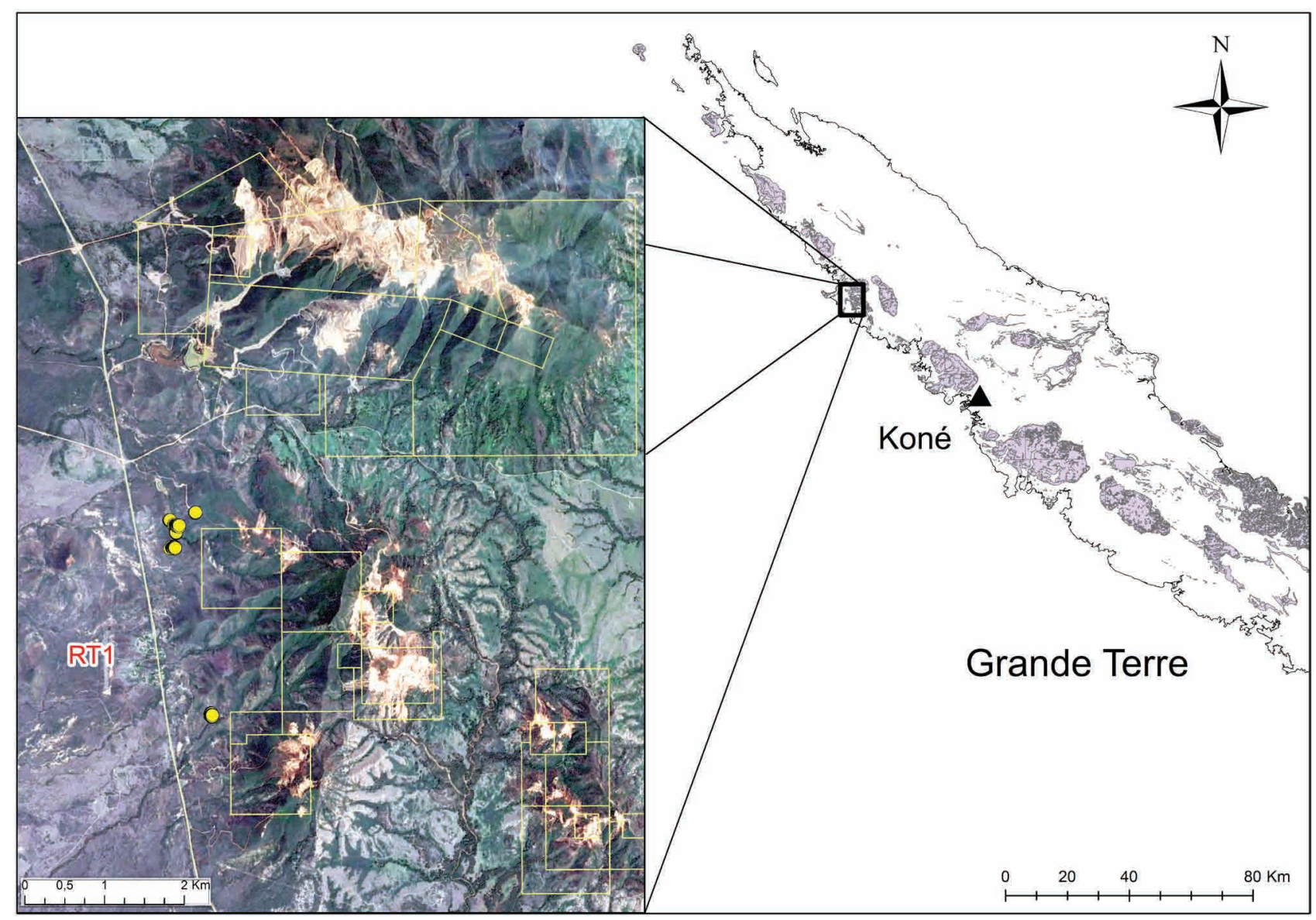

FIGURE 2. Distribution of Pycnandra longiflora based on GPS recorded individuals. Image (C 2016 CNES / Astrium provided by GoogleEarth, lines are Cadastre Minier provided by DIMENC.

\section{What does this discovery teach us about Vieillard's collections?}

An important early explorer in New Caledonia was Eugène Vieillard (1819-1896) and many types are based on his collections (more than 150 species have the epithet "vieillardii"). However, his numbering system was awkward and Morat (2010) finds it "special and irrational", and he indeed used a system in which he numbered the species as he perceived them instead of giving each collection a unique number. This has caused much confusion for his successors, a problem scientists still struggle with. The worst case known was found in Sorthocalyx (Sapindaceae), where three different species of the same genus were mixed in a "single type collection" (Pierre et al. 2014). In addition, Vieillard used only a few locality names, such as Canala, Gatope, Balade and Wagap, which were military posts and probably represent very vague areas and not the real villages having these names (MacKee \& MacKee 1981). Therefore, we assume that Deplanche used "Gatope" in the same meaning as Vieillard and most likely referred to the North-Western quarter of the main island, Grande Terre. Thus, if a taxon is sought 
in a location such as Canala, Balade, Gatope or Wagap, following information provided by Vieillard, we suspect that a much larger area of the coast and mountains should be surveyed.

\section{Conclusion}

Pycnandra longiflora is not extinct and grows less than 600 metres from the main road (RT1) of "Grande-Terre", close to an accessible track (Figure 2). This is a very important locality of native vegetation as a new species of Myrtaceae, Eugenia plurinervia Snow, Munzinger \& Callm. (2016: 212), also occurs here. Several other rare species such as Planchonella minutiflora Munzinger \& Swenson (2009: 182), Croton cordatulus Airy Shaw (1978: 387), Euodia tietaensis (Guillaumin) T.G. Hartley (2001: 56) are also present, which clearly indicates that the place has high conservation value. The rediscovery of this P. longiflora supports continuing botanical surveys in New Caledonia, to provide sound data for conservation assessments.

\section{Acknowledgements}

Great thanks to Rosa Scopetra for her valuable observations and sharing passion for plants, Dominique Fleurot and JeanPierre Butin for many field observations of Pycnandra subgen. Leptostylis, DIMENC for providing "cadastre minier", Peter Weston and anonymous reviewers for comments.

\section{References}

Airy Shaw, H.K. (1978) Notes on Malesian and other Asiatic Euphorbiaceae. Kew Bulletin 32: 361-418. http://dx.doi.org/10.2307/4117108

Aubréville, A. (1967) Sapotacées. In: Aubréville A. (Ed.) Flore de la Nouvelle-Calédonie et Dépendances 1. Muséum National d'Histoire Naturelle. Paris, pp. 1-168.

Bachman, S.P., Moat, J., Hill, A.W., de la Torre, J. \& Scott, B. (2011) Supporting Red List threat assessments with GeoCAT: geospatial conservation assessment tool. In: Smith, V. \& Penev, L. (Eds.) e-Infrastructures for data publishing in biodiversity science. ZooKeys 150: $117-126$.

http://dx.doi.org/10.3897/zookeys.150.2109

Bartish, I.V., Swenson, U., Munzinger, J. \& Anderberg, A.A. (2005) Phylogenetic relationships among New Caledonian Sapotaceae (Ericales): molecular evidence for generic polyphyly and repeated dispersal. American Journal of Botany 92: 667-673. http://dx.doi.org/10.3732/ajb.92.4.667

Beauvisage, G. (1901) Genera Montrouzieriana, plantarum Novae Caledoniae. Annales de la Société Botanique de Lyon 26: 1-96.

Bentham, G. \& Hooker, J.D. (1876) Genera Plantarum ad exemplaria imprimis in herbariis Kewensibus seivata definita. Reeve \& Co., London.

Bouchet, P., Jaffré, T. \& Veillon, J.M. (1995) Plant extinction in New Caledonia: protection of sclerophyll forests urgently needed. Biodiversity and Conservation 4: 415-428. http://dx.doi.org/10.1007/BF00058425

Dubard, M. (1912) Les Sapotacées du groupe des Sideroxylinées. Annales du Musée Colonial de Marseille, Série 2 10: 1-90.

Faegri, K. \& Van Der Pijl, L. (1979) Principles of pollination ecology. 3 edn. Pergamon Press, Oxford.

Hartley, T.G. (2001) On the taxonomy and biogeography of Euodia and Melicope (Rutaceae). Allertonia 8: 1-319.

IUCN (2012) IUCN Red List Categories and Criteria: Version 3.1. Second edition. IUCN Species Survival Commission, IUCN, Gland, Switzerland and Cambridge, UK.

Jaffré, T., Bouchet, P. \& Veillon, J.M. (1998) Threatened plants of New Caledonia: Is the system of protected areas adequate? Biodiversity and Conservation 7: 109-135.

http://dx.doi.org/10.1023/A:1008815930865

MacKee, M.E. \& MacKee, H.S. (1981) E. Vieillard et E. Deplanche, deux grands botanistes collecteurs en Nouvelle-Calédonie. Histoire et Nature 17/18: 49-68.

Morat, P. (2010) Les botanistes récolteurs en Nouvelle-Calédonie de 1774 à 2005. Adansonia, sér. 3 32: 159-216. http://dx.doi.org/10.5252/a2010n2a1

Munzinger, J. (2015) Novitates neocaledonicae I: An additionnal Planchonella (Sapotaceae) endemic to Roches de la Ouaième. Phytotaxa 201: 71-78.

http://dx.doi.org/10.11646/phytotaxa.201.1.5

Munzinger, J. \& Swenson, U. (2009) Three new species of Planchonella (Sapotaceae) with a dichotomous and an online key to the genus 
in New Caledonia. Adansonia sér. 3 31: 175-189.

http://dx.doi.org/10.5252/a2009n1a12

Munzinger, J. \& Swenson, U. (2015) Revision of Pycnandra subgenus Leptostylis and description of subgenus Wagapensia (Sapotaceae), a genus endemic to New Caledonia. Australian Systematic Botany 28: 91-110.

http://dx.doi.org/10.1071/SB15010

Pierre, A.-H., Le Moguédec, G., Lowry II, P.P. \& Munzinger, J. (2014) Multivariate morphometric analysis and species delimitation in the endemic New Caledonian genus Storthocalyx (Sapindaceae). Botanical Journal of the Linnean Society 176: 127-146.

http://dx.doi.org/10.1111/boj.12199

Snow, N., Munzinger, J. \& Callmander, M.W. (2016) Novitates neocaledonicae V: Eugenia plurinervia N. Snow, Munzinger \& Callm. (Myrtaceae), a new threatened species with distinct leaves. Candollea 71: 195-203.

http://dx.doi.org/10.15553/c2016v712a7

Swenson, U. \& Munzinger, J. (2009) Revision of Pycnandra subgenus Pycnandra (Sapotaceae), a genus endemic to New Caledonia. Australian Systematic Botany 22: 437-465.

http://dx.doi.org/10.1071/SB09029

Swenson, U. \& Munzinger, J. (2010a) Revision of Pycnandra subgenus Achradotypus (Sapotaceae), with five new species from New Caledonia. Australian Systematic Botany 23: 185-216. http://dx.doi.org/10.1071/SB09049

Swenson, U. \& Munzinger, J. (2010b) Revision of Pycnandra subgenus Sebertia (Sapotaceae) and a generic key to the family in New Caledonia. Adansonia sér. 3 32: 239-249.

http://dx.doi.org/10.5252/a2010n2a5

Swenson, U. \& Munzinger, J. (2010c) Taxonomic revision of Pycnandra subgenus Trouettia (Sapotaceae), with six new species from New Caledonia. Australian Systematic Botany 23: 333-370.

http://dx.doi.org/10.1071/SB10025

Swenson, U. \& Munzinger, J. (2012) Revision of Pichonia (Sapotaceae) in New Caledonia. Australian Systematic Botany 25: 31-48. http://dx.doi.org/10.1071/SB11027

Swenson, U. \& Munzinger, J. (2016) Five new species and a systematic synopsis of Pycnandra (Sapotaceae), the largest endemic genus in New Caledonia. Australian Systematic Botany 29: 1-40. http://dx.doi.org/10.1071/SB16001

Swenson, U., Bartish, I.V. \& Munzinger, J. (2007a) Phylogeny, diagnostic characters, and generic limitation of Australasian Chrysophylloideae (Sapotaceae, Ericales): Evidence from ITS sequence data and morphology. Cladistics 23: $201-228$. http://dx.doi.org/10.1111/j.1096-0031.2006.00141.x

Swenson, U., Munzinger, J. \& Bartish I.V. (2007b) Molecular phylogeny of Planchonella (Sapotaceae) and eight new species from New Caledonia. Taxon 56: 329-354.

Swenson, U., Lowry II, P.P., Munzinger, J., Rydin, C. \& Bartish, I.V. (2008) Phylogeny and generic limits in the Niemeyera complex of New Caledonian Sapotaceae: evidence of multiple origins of the anisomerous flower. Molecular Phylogenetics and Evolution 49: 909-929.

http://dx.doi.org/10.1016/j.ympev.2008.09.022

Swenson, U., Nylinder, S. \& Munzinger, J. (2013) Towards a natural classification of Sapotaceae subfamily Chrysophylloideae in Oceania and Southeast Asia based on nuclear sequence data. Taxon 62: 746-770.

http://dx.doi.org/10.12705/624.11

Swenson, U., Munzinger, J., Lowry II, P.P., Cronholm, B. \& Nylinder, S. (2015) Island life - classification, speciation, and cryptic species of Pycnandra (Sapotaceae) in New Caledonia. Botanical Journal of the Linnean Society 179: 57-77.

http://dx.doi.org/10.1111/boj.12308

Vink, W. (1957) Revision of the Sapotaceae of the Malaysian area in a wider sense. X. Leptostylis Bentham. Nova Guinea, n.s. 8: 87-98. 